\title{
Penentuan Keseimbangan Protein dan Energi Ransum Sapi Bali Jantan
}

\author{
Determination of Protein - Energy Ratio at Bali Bull Ration
}

\author{
N. P. Mariani, I. G. Mahardika, S. Putra dan I. B. G. Partama \\ Laboratorium Nutrisi dan Makanan Ternak \\ Fakultas Peternakan, Universitas Udayana Denpasar Bali \\ email : mariani.putu10@gmail.com \\ (Diterima: 18 Oktober 2014; Disetujui: 28 Desember 2014 )
}

\begin{abstract}
ABSTRAK
Penelitian ini bertujuan untuk mengetahui keseimbangan energi dan protein sapi Bali jantan yang diberi ransum dengan level protein dan energi. Rancangan yang digunakan : rancangan acak kelompok (RAK) dengan lima perlakuan dan tiga kelompok bobot badan. Bobot sapi berkisar 198,67 - 207,00 kg. Kelima perlakuan ransum yaitu: (A) $15,42 \%$ protein dan GE 4,02 Mkal $/ \mathrm{kg}$ DM; (B) 14,74\% protein dan GE 3,75 Mkal/kg DM; (C) 13,11\% protein dan GE 3,79 Mkal $/ \mathrm{kg}$ DM; (D) 10,33\% protein dan GE 3,92 Mkal/kg DM dan (E) 10,58\% protein dan GE 3,53 Mkal/kg DM. Peubah yang diukur : konsumsi energi, konsumsi protein, energi tercerna, protein tercerna, energi termetabolis, retensi energi dan retensi protein. Hasil penelitian menunjukkan konsumsi energi, energi tercerna dan energi termetabolis tidak menunjukkan perbedaan yang nyata $(\mathrm{P}>0,05)$, sedangkan konsumsi protein, protein tercerna, retensi energi dan retensi protein pada perlakuan A nyata lebih tinggi $(\mathrm{P}<0,05)$ dibandingkan dengan perlakuan $\mathrm{E}$. Hasil penelitian ini dapat disimpulkan konsumsi energi, konsumsi protein, energi tercerna, protein tercerna, retensi energi dan retensi protein tertinggi pada imbangan $15,42 \%$ protein dan GE 4,02 Mkal $/ \mathrm{kg} \mathrm{DM}$.
\end{abstract}

Kata kunci: keseimbangan protein dan energi, sapi bali jantan

\section{ABSTRACT}

The research was conducted to determine protein to energy ratio of Bali bull rations (body weight ranged from 198.67 to $207.00 \mathrm{~kg}$ ) fed at certain levels. The experiment used a randomized block design (RCBD) with five treatments and three weight group replications. The treatments consisted of various P-E ratios, namely; (A) protein $15.42 \%$ and GE $4.02 \mathrm{Mcal} / \mathrm{kg} \mathrm{DM}$; (B) protein $14.74 \%$ and GE $3.75 \mathrm{Mcal} / \mathrm{kg} \mathrm{DM}$; (C) protein $13.11 \%$ and GE $3.79 \mathrm{Mcal} / \mathrm{kg} \mathrm{DM}$; (D) protein $10.33 \%$ and GE $3.92 \mathrm{Mcal} / \mathrm{kg} \mathrm{DM}$ and $(E) 10.58 \%$ and $\mathrm{GE} 3.53 \mathrm{Mcal} / \mathrm{kg} \mathrm{DM}$. The variables measured were the consumption of energy and protein, digestible energy, digestible protein, metabolizable energy, energy and protein retention. The results showed that the energy consumption, digestible energy and metabolizable energy did not show significant differences $(P>$ $0.05)$, whereas protein consumption, digestible protein, energy and protein retention for treatment A was significantly higher $(P<0,05)$ than treatment $E$. In conclusion, treatment A $(15,42 \%$ protein and GE 4,02 Mcal/kg DM )resulted in the highest level of the energy and protein consumption, digestible energy, digestible protein, and retention of energy and protein.

Keywords: protein to energy ratio, bali cattle.

\section{PENDAHULUAN}

Sapi Bali merupakan salah satu plasma nutfah asli Indonesia yang mempunyai potensi genetik dan nilai ekonomis yang cukup tinggi untuk dikembangkan sebagai ternak potong. Sapi Bali memiliki beberapa keunggulan antara lain : tingkat reproduksi yang sangat 
tinggi seperti angka kebuntingan berkisar 80 $90 \%$, tingkat kelahiran $75-85 \%$ dan nilai karkas $56 \%$ serta kualitas daging cukup baik (Soehadji, 1991).

Pemeliharaan sapi Bali di tingkat petani umumnya bersifat tradisional dan sambilan. Salah satu cirinya adalah pakan yang diberikan hanya mengandalkan pada hijauan berbasis rumput-rumputan tanpa memperhatikan kandungan nutriennya. Walaupun ada peternak yang memberikan pakan dengan tambahan dedak padi, namun dari segi kecukupan dan keseimbangan nut-riennya belum menjamin pencapaian produk-tivitas yang optimal. Pemenuhan kebutuhan ternak akan nutrien yang cukup dan seimbang penting diperhatikan, karena hal ini merupa-kan salah satu faktor lingkungan yang besar pengaruhnya terhadap pertumbuhan dan produksi ternak (Maryono, 2006).

Protein dan energi merupakan nutrien penting yang harus diperhatikan dalam menyusun ransum untuk ternak ruminansia. Leng (1991) menyatakan bahwa imbangan protein dan energi ransum sangat menentukan efisiensi pemanfaatan nutrien yang akhirnya berpengaruh pada produktivitas ternak. Oleh karena itu, formula ransum dengan nutrien yang cukup dan seimbang dapat menghasilkan produktivitas ternak sesuai dengan potensi genetiknya. Keseimbangan energi dan protein merupakan keseimbangan antara jumlah energi dan protein yang dikonsumsi dengan energi dan protein yang dikeluarkan dari tubuh. Besarnya keseimbangan energi menunjukkan besarnya energi yang dapat dimanfaatkan dan disimpan sebagai jaringan baru di dalam tubuh. Untuk tujuan produksi dalam hal ini adalah pertambahan bobot badan, sedangkan keseimbangan protein secara umum menunjukkan status nutrisi pakan ternak. Proses penyimpanan atau pengurangan protein dalam tubuh, merupakan cerminan dari protein dalam ransum yang diberikan apakah cukup memenuhi kebutuhannya ataukah menjadi dirombaknya jaringan tubuh untuk memenuhi kebutuhannya (Tillman et al., 1998).

Cakra et al. (2010) melaporkan bahwa sapi Bali yang diberi ransum jerami padi amoniasi dengan kandungan protein $14,5 \%$ dan energi 3,88GE Mkal yang disuplementasi multi vitamin-mineral dapat memperbaiki keseimbangan proteinnya. Di lain pihak Suryani et al. (2012) melaporkan sapi bali jantan yang diberi ransum dengan protein $12 \%$ dan energi $3.109 \mathrm{kkal} / \mathrm{kg}$ menghasilkan keseimbangan energi terbaik dengan komposisi bahan pakan 30\% jerami padi, 30\% gamal, $10 \%$ kaliandra serta $30 \%$ konsentrat. Berdasarkan uraian di atas maka dilakukanlah penelitian untuk mengetahui keseimbangan energi dan protein pada sapi bali yang diberikan ransum dengan level protein dan energi.

\section{METODE}

Penelitian dilaksanakan pada kelompok ternak Wibuh Mandiri, di Banjar Tangkeban Desa Batubulan Kangin, Kecamatan Sukawati, Kabupaten Gianyar. Masa adaptasi selama 10 hari dan pengam-bilan data dilakukan selama 12 minggu.

Rancangan percobaan yang digunakan adalah rancangan acak kelompok (RAK) yang terdiri dari lima perlakuan ransum dan tiga kelompok bobot badan sebagai ulangan. Sapi bali jantan dengan bobot badan awal berkisar 198,67-207,00 kg, sebanyak 15 ekor. Ransum yang diberikan adalah ransum komplit dalam bentuk mash, diberikan secara ad libitum. Komposisi dan kandungan nutrien ransum seperti Tabel 1 dan 2.

Peubah yang diukur adalah keseimbangan energi (konsumsi energi, energi tercerna, energi termetabolis, dan retensi energi), dan keseimbangan protein (konsumsi protein, protein tercerna, dan retensi protein).

\section{Retensi Energi (RE)}

Retensi energi (RE) dapat diketahui dengan cara mengkonversi hasil pengukuran dari deposisi lemak dan protein berdasarkan komposisi tubuh menjadi retensi energi, dengan ketentuan deposisi $1 \mathrm{~g}$ protein tubuh mengandung 5,5 kcal dan deposisi $1 \mathrm{~g}$ lemak tubuh mengandung 9,32 kcal (Orskov dan Ryle, 
Tabel 1. Komposisi bahan penyusun ransum

\begin{tabular}{lrrrrr}
\hline \multirow{2}{*}{ Bahan Pakan (\%) } & \multicolumn{5}{c}{ Perlakuan } \\
\cline { 2 - 6 } & $\mathrm{A}$ & $\mathrm{B}$ & $\mathrm{C}$ & $\mathrm{D}$ & $\mathrm{E}$ \\
\hline Rumput gajah & 10,0 & 15,0 & 27,0 & 40,0 & 55,0 \\
Gamal & 25,0 & 20,0 & 8,0 & 5,0 & 0,0 \\
Pollar & 5,5 & 10,0 & 14,5 & 10,5 & 5,5 \\
Bungkil kelapa & 17,0 & 11,5 & 10,0 & 5,0 & 2,0 \\
Tepung gaplek & 35,0 & 38,0 & 36,0 & 35,0 & 33,0 \\
Molases & 4,0 & 4,0 & 3,0 & 3,0 & 3,0 \\
Minyak kelapa & 2,0 & 0,0 & 0,0 & 0,0 & 0,0 \\
Urea & 1,0 & 1,0 & 1,0 & 1,0 & 1,0 \\
Garam $(\mathrm{NaCl})$ & 0,4 & 0,4 & 0,4 & 0,4 & 0,4 \\
Pignox & 0,1 & 0,1 & 0,1 & 0,1 & 0,1 \\
\hline Total & 100 & 100 & 100 & 100 & 100 \\
\hline
\end{tabular}

Tabel 2. Kandungan nutrien ransum ${ }^{1)}$

\begin{tabular}{lrrrrrc}
\hline & \multicolumn{9}{c}{ Perlakuan $^{2)}$} & \multicolumn{2}{c}{$\begin{array}{c}\text { Standar } \\
\text { Kearl, } \\
\text { Kandungan Nutrien (\% DM) }\end{array}$} \\
\cline { 2 - 7 } & \multicolumn{1}{c}{ A } & \multicolumn{1}{c}{ B } & \multicolumn{1}{c}{ C } & D & E & 1982 \\
\hline Bahan kering & 89,49 & 90,00 & 90,63 & 89,73 & 90,58 & - \\
Lemak kasar & 4,09 & 3,67 & 1,76 & 2,52 & 2,33 & - \\
Serat kasar & 17,81 & 17,58 & 19,36 & 20,29 & 21,23 & - \\
Protein kasar & 15,42 & 14,74 & 13,11 & 10,33 & 10,58 & - \\
GE(kcal/kg) & 4020 & 3747 & 3790 & 3920 & 3535 & - \\
Ca & 0,92 & 0,99 & 0,92 & 1,03 & 0,70 & 0,48 \\
P & 0,10 & 0,12 & 0,07 & 0,11 & 0,06 & 0,30 \\
\hline
\end{tabular}

Keterangan: 1). Hasil analisa Laboratorium Nutrisi, Kelompok Kerja Penelitian Sapi Potong Grati, Jawa Timur (2011).

2). A: ransum dengan protein $15,42 \%$ dan GE $4,02 \mathrm{Mcal} / \mathrm{kgDM}$

B: ransum dengan protein $14,74 \%$ dan GE $3,75 \mathrm{Mcal} / \mathrm{kgDM}$

C: ransum dengan protein $13,11 \%$ dan GE $3,79 \mathrm{Mcal} / \mathrm{kgDM}$

D: ransum dengan protein $10,33 \%$ dan GE 3,92 Mcal $/ \mathrm{kgDM}$

E: ransum dengan protein $10,58 \%$ dan GE 3,53 Mkal $/ \mathrm{kgDM}$

3). Hasil analisa Laboratorium Nutrisi IPB, Bogor (2011).

Keseimbangan energi dihitung berdasarkan persamaan:

1. Energi Tercerna $(\mathrm{DE}) \quad=$ Energi yang dikonsumsi - Energi yang keluar lewat feses

2. Energi Termetabolis (ME) $=\mathrm{DE}-($ energi urin + Energi methan $)$ atau

Energi Termetabolis $(\mathrm{ME})=$ Energi yang dikonsumsi $-($ Energi feses + Energi urin + Energi methan)

1990). Pengukuran komposisi tubuh dengan menggunakan teknik Ruang Urea (Urea space) menurut metode Bartle et al. (1983). Deposisi nutrien yang dihitung adalah deposisi lemak dan protein dapat dihitung dengan rumus sebagai berikut:

Deposisi protein $(\mathrm{g} / \mathrm{h})=\%$ protein tubuh $\mathrm{x}$ pbbh

Deposisi lemak $(\mathrm{g} / \mathrm{h})=\%$ lemak tubuh $\mathrm{x}$ pbbh 
Retensi energi dapat ditentukan dengan rumus: Keterangan:

$$
\mathrm{RE}=(\mathrm{DP} \times 5,5)+(\mathrm{DL} \times 9,32)
$$

$$
\begin{aligned}
& \mathrm{RE}=\operatorname{Retensi~Energi~}(\mathrm{kcal} / \mathrm{h}) \\
& \mathrm{DP}=\operatorname{Deposisi} \text { Protein }(\mathrm{g} / \mathrm{h}) \\
& \mathrm{DL}=\operatorname{Deposisi} \operatorname{Lemak}(\mathrm{g} / \mathrm{h})
\end{aligned}
$$

\section{Produksi Panas (PP)}

Produksi panas/pengeluaran energi adalah energi yang diperlukan oleh hewan dalam keadaan istirahat maupun kerja. Produksi panas ditentukan dengan rumus:

$$
\mathrm{PP}=\mathrm{ME}-\mathrm{RE}
$$

Keterangan :

$$
\begin{aligned}
& \mathrm{PP}=\text { Produksi Panas }(\mathrm{kkal} / \mathrm{h}) \\
& \mathrm{ME}=\text { Energi Termetabolis }(\mathrm{kkal} / \mathrm{h}) \\
& \mathrm{RE}=\text { retensi energi }(\mathrm{kkal} / \mathrm{h})
\end{aligned}
$$

Keseimbangan protein dihitung berdasarkan persamaan:

Konsumsi protein $=$ Konsumsi ransum $(\mathrm{gBK}) \times \%$ protein ransum

Defekasi protein $=$ Produksi feses $(\mathrm{gBK}) \times \%$ protein feses

Ekskresi protein urin $=$ Produksi urin $(\mathrm{ml}) \times \%$ protein urin

Pengambilan data dilakukan dengan metode koleksi total selama 7 hari pada minggu terakhir dari penelitian. Pengamatan selama koleksi total dilakukan mulai pukul 08.00 sampai 08.00 WITA keesokan harinya. Pengambilan sampel harian ransum yang diberi dan sisa diambil sebanyak $200 \mathrm{~g}$, dicampur, diambil masing-masing $200 \mathrm{~g}$ untuk dilakukan analisa laboratorium. Demikian juga dengan fesesnya. Sampel feses diambil 5\% dari total feses setiap hari, kemudian dikeringkan dengan sinar matahari dan dikomposit pada akhir penelitian. Masingmasing ternak diambil $200 \mathrm{~g}$ untuk dianalisa kandungan nutriennya, menurut metode AOAC (1990).

Pengukuran produksi urin dilakukan dengan memasang "harnest" yang dibuat dari ban bekas dipasangkan pada bagian penis sapi yang melingkari perutnya. Pada bagian bawah "harnest" dihubungkan dengan selang plastik dengan derigen sebagai penampung urin.
Sampel urin diambil sebanyak $100 \mathrm{ml} / \mathrm{hari}$ dan langsung ditetesi $\mathrm{HCl} 75 \%$ dengan tujuan untuk mencegah penguapan $\mathrm{N}$ dalam urin.

Data yang diperoleh dari hasil penelitian dianalisis dengan sidik ragam. Apabila terdapat hasil yang berbeda nyata $(\mathrm{P}<0,05)$ maka dilanjutkan dengan uji jarak berganda Duncan pada taraf 5\% (Steel dan Torrie, 1993).

\section{HASIL DAN PEMBAHASAN}

\section{Keseimbangan Energi}

Keseimbangan energi merupakan keseimbangan antara jumlah energi yang dikonsumsi dengan energi yang dikeluarkan dari tubuh. Besarnya keseimbangan energi menunjukkan besarnya energi yang dapat dimanfaatkan dan disimpan sebagai jaringan baru di dalam tubuh. Rataan konsumsi energi, energi yang keluar lewat feses, energi tercerna, energi yang hilang sebagai metan, energi termetabolis, dan produksi panas pada sapi bali yang diberi ransum dengan level protein dan energi, menunjukkan perbedaan yang tidak nyata $(\mathrm{P}>0,05)$ pada semua perlakuan (Tabel 3). Energi termetabolis tertinggi didapatkan pada sapi yang mendapat perlakuan $\mathrm{D}$ yaitu sebesar 11476,47 kkal/e/h. Jumlah energi termetabolis merupakan energi tercerna dikurangi dengan energi yang hilang lewat urin dan gas methan. Energi termetabolis digunakan untuk kepentingan pemeliharaan jaringan tubuh, untuk produksi dan berubah menjadi panas atau energi yang hilang sebagai panas (Tillman et al., 1998). Melalui perhitungan dengan menggunakan nilai setara kalor dalam komposisi protein dan lemak tubuh dengan teknik ruang urea diperoleh nilai retensi energi. Retensi energi hasil penelitian ini berkisar dari 831,47-1467,81 kkal/e/h sama dengan $13,75-23,65 \mathrm{kkal} / \mathrm{W}^{0,75} / \mathrm{h}$. Penelitian yang dilakukan oleh Suryani et al. (2012) pada sapi Bali yang diberi pakan hijauan dengan jenis dan komposisi berbeda menghasilkan retensi energi yang lebih tinggi yaitu 23,99-33,33 $\mathrm{kkal} / \mathrm{W}^{0,75} / \mathrm{h}$. Retensi energi merupakan bagian energi yang disimpan sebagai jaringan baru 
sebagai produk pertumbuhan yaitu lemak dan protein (Tillman et al., 1998).

Perhitungan produksi panas dengan pengukuran energi termetabolis (ME) dan retensi energi (RE) didapatkan bahwa produksi panas sapi bali jantan pada perlakuan A, B, C, D dan E masing-masing adalah 8620,25; 8308,$03 ; 8654,27 ; 9889,96$ dan E 7069,96 kkal/e/h (Tabel 3).

Produksi panas berkisar antara 7069,96$9889,96 \mathrm{kkal} / \mathrm{e} / \mathrm{h}$ atau setara dengan $0,50-0,66$ $\mathrm{MJ} / \mathrm{W}^{0,75}$. Trisnadewi (2008) mendapatkan produksi panas sapi bali yang diberi ransum berbasis jerami padi amoniasi dengan supplementasi multi vitamin-mineral adalah 0,480,59 MJ/W $\mathrm{W}^{0,75}$, sedangkan Suryani (2012) mendapatkan produksi panas sapi Bali yang diberi pakan hijauan dengan jenis dan komposisi berbeda adalah 0,40-0,59 MJ/ $\mathrm{W}^{0,75}$.

\section{Keseimbangan Protein}

Keseimbangan protein suatu bahan pakan dipengaruhi oleh konsumsi, feses dan perbedaan yang nyata, sedangkan perlakuan $D$ dan $\mathrm{E}$ nyata menurun dibandingkan dengan perlakuan A (Tabel 4). Menurunnya protein yang dapat dicerna pada sapi perlakuan D dan
E disebabkan oleh kualitas ransumnya semakin menurun, sehingga ketersediaan nutrien akan menurun, sehingga berpengaruh terhadapap pertumbuhan ternak. Tingkat kecernaan pakan dipengaruhi oleh beberapa komponen yaitu komposisi kimia, serat kasar, tingkat protein ransum dan jumlah ransum yang dikonsumsi (Bernard dan MCNeill, 1991; Allen,2000). Disamping itu menurut Bach et al. (2005) kecernaan protein juga dipengaruhi oleh tipe protein dan interaksinya dengan nutrien lain (jenis pakan, laju alir dan $\mathrm{pH}$ rumen).

Apabila protein yang dapat dicerna dihitung berdasarkan berat badan metabolik $\left(\mathrm{DP} / \mathrm{W}^{0,75}\right)$, juga hasilnya menunjukkan perbedaan yang nyata $(\mathrm{P}<0,05)$ di antara semua perlakuan. Sapi yang mendapatkan perlakuan C berada pada urutan pertama, selanjutnya pada perlakuan A, B, E dan D yaitu masingmasing 7,76; 6,58; 6,57; 4,81 dan 4,23 g/e/ $\mathrm{W}^{0,75}$. Protein yang keluar melalui feses meliputi protein yang tidak tecerna dan protein endogenous yang merupakan substansi yang berasal dari tubuh, seperti enzim yang endogenous yang merupakan

Tabel 3. Keseimbangan energi pada sapi Bali yang diberi ransum dengan level protein dan energi yang berbeda $(\mathrm{kkal} / \mathrm{e} / \mathrm{h})$

\begin{tabular}{|c|c|c|c|c|c|c|}
\hline \multirow{2}{*}{ Variabel } & \multicolumn{5}{|c|}{ Perlakuan } & \multirow{2}{*}{ SEM } \\
\hline & A & $\mathrm{B}$ & $\mathrm{C}$ & $\mathrm{D}$ & $\mathrm{E}$ & \\
\hline Konsumsi energi & $20119,10^{\mathrm{a}}$ & $20222,52^{\mathrm{a}}$ & $18710,74^{\mathrm{a}}$ & $20726,74^{\mathrm{a}}$ & $17302,76^{\mathrm{a}}$ & 1081,72 \\
\hline Energi Feses & $7115,09^{\mathrm{a}}$ & $7560,68^{a}$ & $5833,66^{\mathrm{a}}$ & $7158,32^{\mathrm{a}}$ & $7155,28^{\mathrm{a}}$ & 532,39 \\
\hline Energi Tercerna & $13004,01^{\mathrm{a}}$ & $12661,84^{\mathrm{a}}$ & $12877,08^{\mathrm{a}}$ & $13568,42^{\mathrm{a}}$ & $10147,47^{\mathrm{a}}$ & 672,43 \\
\hline Energi Urin & $677,36^{\mathrm{ab}}$ & $677,74^{\mathrm{ab}}$ & $844,55^{\mathrm{a}}$ & $433,81^{\mathrm{b}}$ & $505,47^{\mathrm{b}}$ & 74,18 \\
\hline Energi Metan & $1609,53^{\mathrm{a}}$ & $1617,80^{\mathrm{a}}$ & $1496,86^{\mathrm{a}}$ & $1658,14^{\mathrm{a}}$ & $1384,22^{\mathrm{a}}$ & 86,54 \\
\hline Energi Termetabolis & $10717,12^{\mathrm{a}}$ & $10366,30^{\mathrm{a}}$ & $10535,67^{a}$ & $11476,47^{\mathrm{a}}$ & $8257,78^{a}$ & 584,95 \\
\hline Retensi Energi & $1467,81^{\mathrm{a}}$ & $1440,78^{\mathrm{ab}}$ & $1316,98^{\mathrm{ab}}$ & $1110,56^{\mathrm{bc}}$ & $831,47^{\mathrm{c}}$ & 103,17 \\
\hline Produksi Panas & $8620,25^{\mathrm{a}}$ & $8308,03^{\mathrm{a}}$ & $8654,27^{\mathrm{a}}$ & $9889,96^{\mathrm{a}}$ & $7069,96^{\mathrm{a}}$ & 650,59 \\
\hline Produksi Panas MJ/W' $\mathrm{W}^{0,75}$ & $0,58^{a}$ & $0,56^{\mathrm{a}}$ & $0,58^{\mathrm{a}}$ & $0,66^{\mathrm{a}}$ & $0,50^{\mathrm{a}}$ & 10,27 \\
\hline
\end{tabular}

Keterangan:

A: ransum dengan protein $15,42 \%$ dan GE 4,02 Mcal/kg DM

B: ransum dengan protein $14,74 \%$ dan GE $3,75 \mathrm{Mcal} / \mathrm{kg}$ DM

C: ransum dengan protein $13,11 \%$ dan GE $3,79 \mathrm{Mcal} / \mathrm{kg} \mathrm{DM}$

D: ransum dengan protein $10,33 \%$ dan GE 3,92 Mcal/kg DM

E: ransum dengan protein $10,58 \%$ dan GE $3,53 \mathrm{Mcal} / \mathrm{kg} \mathrm{DM}$

Superskrip yang berbeda pada baris yang sama adalah berbeda nyata $(\mathrm{P}<0,05)$

SEM : "Standard Error of the treatment means" 
Tabel 4. Keseimbangan Protein pada Sapi Bali yang Diberi Ransum dengan Level Protein dan Energi $(\mathrm{g} / \mathrm{e} / \mathrm{h})$

\begin{tabular}{|c|c|c|c|c|c|c|}
\hline \multirow{2}{*}{ Variabel } & \multicolumn{5}{|c|}{ Perlakuan } & \multirow{2}{*}{ SEM } \\
\hline & A & $\mathrm{B}$ & $\mathrm{C}$ & $\mathrm{D}$ & $\mathrm{E}$ & \\
\hline Konsumsi Protein & $771,69^{a}$ & $795,35^{\mathrm{a}}$ & $651,75^{\mathrm{ab}}$ & $546,26^{\mathrm{b}}$ & $517,69^{\mathrm{b}}$ & 55,46 \\
\hline Protein dalam Feses & $363,44^{\mathrm{ab}}$ & $368,54^{\mathrm{a}}$ & $175,43^{\mathrm{c}}$ & $274,38^{\mathrm{abc}}$ & $230,09^{\mathrm{bc}}$ & 39,78 \\
\hline Jumlah Protein Tercerna & $408,25^{\mathrm{a}}$ & $406,81^{\mathrm{a}}$ & $476,32^{\mathrm{a}}$ & $271,88^{\mathrm{b}}$ & $287,60^{\mathrm{b}}$ & 33,75 \\
\hline Protein Urin & $314,76^{\mathrm{ab}}$ & $314,94^{\mathrm{ab}}$ & $392,45^{\mathrm{a}}$ & $201,58^{b}$ & $234,89^{b}$ & 34,47 \\
\hline Protein Teretensi & $93,49^{\mathrm{a}}$ & $91,88^{\mathrm{a}}$ & $83,88^{\mathrm{a}}$ & $70,30^{\mathrm{ab}}$ & $52,72^{\mathrm{b}}$ & 7,11 \\
\hline \multicolumn{7}{|l|}{ eterangan: } \\
\hline $\begin{array}{l}\text { A: ransum dengan pro } \\
\text { B: ransum dengan pro } \\
\text { C: ransum dengan pro } \\
\text { D: ransum dengan pro } \\
\text { E: ransum dengan pro } \\
\text { Superskrip yang berb } \\
\text { SEM : "Standard Err }\end{array}$ & $\begin{array}{l}15,42 \% \text { da } \\
14,74 \% \text { da } \\
13,11 \% \text { da } \\
10,33 \% \text { da } \\
10,58 \% \text { da } \\
\text { ada baris y } \\
\text { The Treatn }\end{array}$ & $\begin{array}{l}\text { GE } 4,02 \mathrm{~N} \\
\text { GE 3,75 N } \\
\text { GE 3,79 N } \\
\text { GE 3,92 N } \\
\text { GE 3,53 M } \\
\text { g sama ad, } \\
\text { nt means" }\end{array}$ & $\begin{array}{l}11 / \mathrm{kg} \mathrm{DM} \\
11 / \mathrm{kg} \mathrm{DM} \\
1 / \mathrm{kg} \mathrm{DM} \\
1 / \mathrm{kg} \mathrm{DM} \\
1 / \mathrm{kg} \mathrm{DM} \\
\mathrm{h} \text { berbeda }\end{array}$ & ata $(\mathrm{P}<0,0$ & & \\
\hline
\end{tabular}

substansi yang berasal dari tubuh, seperti enzim yang disekresikan ke dalam saluran pencernaan yang tidak diabsorpsi kembali, sel-sel epitel saluran pencernaan yang terkikis oleh material pakan serta residu mikroba. Van Soest (1994) menyatakan bahwa faktor yang mempengaruhi pengeluaran nitrogen feses adalah nitrogen yang tercerna dan efisiensi penggunaan mikroba dalam rumen.

Protein yang teretensi nyata semakin meningkat dengan semakin meningkatnya level protein dan energi di dalam ransum $(\mathrm{P}<0,05)$. Melalui perhitungan dengan mengalikan nilai rataan pertambahan bobot badan dengan komposisi protein dalam teknik ruang urea diperoleh nilai retensi protein. Retensi protein pada sapi bali yang mendapat perlakuan A, B, C , D dan E masing-masing adalah 93,$49 ; 91,88 ; 83,88 ; 70,30$ dan $52,72 \mathrm{~g} / \mathrm{e} / \mathrm{h}$ (Tabel 4). Hasil penelitian ini menunjukkan walaupun konsumsi protein pada sapi yang mendapat perlakuan A berada di antara konsumsi protein perlakuan $\mathrm{B}$ dan $\mathrm{C}$, namun protein yang diretensi adalah tertinggi kemudian perlakuan B dan C. Hal ini disebabkan sapi yang mendapat perlakuan A lebih banyak dapat menahan protein dalam tubuhnya dan sedikit yang dibuang melalui feses dan urin sehingga sapi dapat mencerna dan mengabsorbsi protein lebih efisien. Menurut Mathius et al., (2002) ketersediaan dan efisiensi penggunaan protein suatu ransum oleh ternak dapat diketahui dari selisih antara jumlah protein yang dikonsumsi dan yang dikeluarkan oleh tubuh baik melalui feses maupun urine.

\section{KESIMPULAN}

Berdasarkan hasil penelitian ini dapat disimpulkan bahwa keseimbangan energi dan protein (konsumsi energi, konsumsi protein, energi tercerna, protein tercerna, retensi energi dan retensi protein) tertinggi dihasilkan pada sapi yang mendapat perlakuan A (ransum dengan protein $15,42 \%$ dan GE 4,02 Mcal $/ \mathrm{kg}$ DM).

\section{UCAPAN TERIMAKASIH}

Pada kesempatan ini penulis mengucapkan terimakasih kepada Dekan Fakultas Peternakan Udayana dan Rektor Universitas Udayana yang telah memberikan ijin dan menyediakan fasilitas dalam penelitian ini. Juga terimakasih penulis ucapkan kepada kelompok Ternak Wibuh Mandiri atas kerjasamanya selama penelitian.

\section{DAFTAR PUSTAKA}

Allen, MS. 2000. Effects ot diet on short-term regulation of feed intake by lactating 
dairy cattle. J. Dairy Sci. 83 : Issue 7 : 1598-1624.

A.O.A.C. 1990. Official Method of Analysis. 13th Ed. Association of Official Analytical Chemist. Washington, DC.

Bach, A, Calsamiglia, S and Stern, MD. 2005. Nitrogen metabolism in the rumen. $J$. Dairy Sci. 88 : (E.Suppl.): E9-E21. American Dairy Science Association.

Bartle, S.J., J.R. Males and R.L. Preston. 1983. Evaluation of urea dilution as an estimator of body composition in mature cows. J.Anim., Vol 57: 410 417.

Bernard, JK and McNeill, JK. 1991. Effect of high fiber energy supplements on nutrient digestibility and milk production of lactating dairy cows. J. Dairy Sci. 83 (3) : 991-995.

Cakra, I.G.L.O., A.A.A.S Trisnadewi, I.B.G. Partama, T.G.B. Yadnya and N.L.G. Sumardani. 2010. Nitrogen balance of bali cattle fed ammoniated rice straw and concentrate supplemented by multi vitamin-mineral. Proc. Conservation and Improvement of World Indigenous Cattle. Bali, 3rd4th September 2010. Held by Study Centre For Bali cattle, Udayana University. 95-109.

Kearl, L.C. 1982. Nutrient requirements of ruminant in developing countries. international feedstuff institute. Utah Agricultural Experiment Station. Logan Utah : Utah State University.

Leng, R.A. 1991. Application of biotechnology to nutrition of animal in developing countries. Rome: Animal Production and Health Paper, FAO.

Maryono. 2006. Teknologi Inovasi "Pakan Murah" untuk Usaha Pembibitan Sapi Potong Lokal. Sinar Tani ed. 18-24 Oktober.
Mathius, I. W., I.B. Gaga, dan I.K. Sutama. 2002. Kebutuhan kambing PE jantan muda akan energi dan protein kasar: konsumsi, kecernaan dan pemanfaatan nitrogen. JITV 7(2):99109.

Orskov, E.R., and Ryle. 1990. Energy Nutrition in Ruminants. London: Elsevier Applied Science.

Soehadji, H. 1991. Kebijakan pengembangan ternak potong di Indonesia. Proc. Seminar Nasional Sapi Bali. 2-3 September.

Steel, R.G.D, dan J.H Torrie, 1993. Prinsip dan Prosedur Statistika: Suatu Pendekatan Biometrik. Edisi II. Terjemahan: B Sumantri. PT Gramedia Pustaka Utama Jakarta. Jakarta.

Suryani, N. N. 2012. Aktivitas mikroba rumen dan produktivas sapi bali yang diberi pakan hijauan dengan jenis dan komposisi berbeda (disertasi). Denpasar: Program Pascasarjana Universitas Udayana.

Suryani , N.N., I.G. Mahardika, S. Putra and N. Sujaya. 2012. Neraca energi dan performan sapi bali yang diberi pakan hijauan dengan jenis dan komposisi berbeda.Pros. Seminar Nasional. "Peningkatan Produksi Dan Kualitas Daging Sapi Bali Nasional". Pusat Kajian Sapi Bali Universitas Udayana. 213-225.

Tillman, A.D., H. Hartadi, S. Reksohadiprodjo, S. Prawirokusumo, dan S. Lebdosoekojo. 1998. Ilmu Makanan Ternak Dasar. Yogyakarta: Gadjah Mada Universirty Press.

Trisnadewi, A.A.A.S. 2008. "Neraca Energi, Neraca Nitrogen dan Deposisi Nutrien pada Sapi Bali yang Diberi Ransum Berbasis Jerami Padi Amoniasi dengan Suplementasi Multi Vitamin-mineral" (tesis). Denpasar: 
Program Pascasarjana Universitas Udayana.
Van Soest, P. J. 1994. Nutritional Ecology of the Rumen. $2^{\text {nd }}$ Edition. New York, Cornell University Press. 